\title{
$\alpha$-Internexin, a Novel Neuronal Intermediate Filament Protein, Precedes the Low Molecular Weight Neurofilament Protein (NF-L) in the Developing Rat Brain
}

\author{
Michael P. Kaplan, Steven S. M. Chin, Karsten H. Fliegner, and Ronald K. H. Liem \\ Departments of Pathology and Anatomy and Cell Biology, Columbia University College of Physicians and Surgeons, New \\ York, New York 10032
}

$\alpha$-Internexin is a $66 \mathrm{kDa}$ protein that copurifies with intermediate filaments (IF) from rat spinal cord and optic nerve. This protein is axonally transported in rat optic nerve along with the neurofilament triplet proteins in slow component a. Polymerization in vitro and distribution in vivo confirm that $\alpha$-internexin is a neuronal IF. We raised 2 highly specific monoclonal antibodies to $\alpha$-internexin which were applied to frozen rat brain sections and Western blots of cytoskeletal extracts. These results indicate that $\alpha$-internexin is primarily an axonal protein found in most, if not all, neurons of the CNS. Immunoreactive proteins of similar molecular weight were found in cytoskeletal extracts of CNS tissue from several additional species, including mouse and cow. While the distribution of $\alpha$-internexin as given by immunocytochemical methods is similar to that of low molecular weight neurofilament protein (NF-L) in the adult, its distribution in the embryo is far more extensive. At embryonic day 16, when the expression of NF-L is still limited to a relatively small number of cells and levels of expression are low, $\alpha$-internexin is already found at much higher levels and in cells not yet expressing NF-L in detectable quantities. Similar results are found at embryonic day 12. These data suggest that neuronal IF in the developing nervous system contain a higher proportion of $\alpha$-internexin than their adult counterparts, and that expression of $\alpha$-internexin precedes that of NF-L in many or most neurons of the developing brain.

Mammalian neuronal intermediate filaments (IF) have long been described in terms of a "neurofilament triplet" of low, medium, and high molecular weight proteins, designated NF-L, NF-M, and NF-H, respectively (Hoffman and Lasek, 1975; Liem et al., 1978 ). Insoluble at physiological $\mathrm{pH}$, they polymerize in vivo to form $10 \mathrm{~nm}$ IFs which traverse the length of the neuronal axoplasm. Filaments composed of variable proportions of the 3 neurofilament proteins can be detected in the axons (and, to a lesser extent, the dendrites and perikarya) of most mature neu-

\footnotetext{
Received March 7, 1990; revised April 24, 1990; accepted April 25, 1990.

We thank Dr. James Goldman and Dr. John Pintar for their expert advice on developmental anatomy, Mr. David Weinstein and Mr. Ray Manson for photographic work, and Ms. Kristy Brown for electron microscopy. This work was supported by Grants NS15182 (Jacob Javits Neuroscience Award) and EYO3849. K.H.F. and S.S.M.C. are supported by a Medical Scientist Training Program Grant at New York University School of Medicine.

Correspondence should be addressed to Dr. Ronald K. H. Liem, Department of Pathology, Columbia University College of Physicians and Surgeons, 630 West 168 th Street, New York, NY 10032.

Copyright (C) 1990 Society for Neuroscience $0270-6474 / 90 / 082735-14 \$ 03.00 / 0$
}

rons in the central and peripheral nervous system. A fourth neuronal intermediate filament protein has recently been described (Portier et al., 1984; Parysek and Goldman, 1987; Leonard et al., 1988); termed "peripherin," this $57 \mathrm{kDa}$ protein is found primarily in processes of the peripheral nervous system. While their exact functions remain unclear, neuronal IFs presumably play some structural role in the generation and/or maintenance of the highly asymmetrical forms of neurons and their processes; for example, it has been suggested that neuronal IFs may be arbiters of neuronal caliber (for review, see Lasek et al., 1983).

Like other IFs, such as glial fibrillary acidic protein (GFA) in astroglia, desmin in smooth muscle cells, and vimentin in cells of mesenchymal origin, the neuronal IF proteins each contain a highly conserved $\alpha$-helical domain, flanked by variable hcad and tail sequences (for review, see Steinert and Roop, 1988); the rod-shaped, $\alpha$-helical domains form the core of the filament, with the variable end sequences projecting outward. The extensive carboxy-terminal end sequence of NF-H is known to participate in the formation of cross-bridges between filaments ( $\mathrm{Hi}$ rokawa et al., 1984). NF-L, but not NF-M or NF-H, is readily able to self-polymerize in vitro at physiological $\mathrm{pH}$ (Liem and Hutchison, 1982); inability of the other isolated subunits to polymerize is probably due to ionic repulsion between their highly phosphorylated tail sequences, and it has recently been suggested that this repulsion between phosphate groups may play a role in maintaining the distance between flaments in vivo (Hirokawa et al., 1984; Carden et al., 1987; Shaw, in press).

Developmental studies using biochemical and immunological methods have shown that neurogenesis is accompanied by changes in neuronal IF composition. After an initial stage during which vimentin may be expressed (Bignami et al., 1982; Cochard and Paulin, 1984), coexpression of NF-L and NF-M precedes that of NF-H in developing rat brain (Shaw and Weber, 1982; Carden et al., 1987), retina (Shaw and Weber, 1983), and optic nerve (Pachter and Liem, 1984). Neuronal IFs containing NF-L and NF-M can be detected as early as embryonic day 12 in some regions, while NF-H may not be expressed until days or weeks after birth in some areas. Hippocampal neurons cultured in vitro display a similar stepwise pattern of expression (Shaw et al., 1985). The significance of this delayed appearance of the larger subunit is probably related to its putative role as cross-linker between filaments and the stabilization of IF structure presumably accompanying neuronal maturation. In the peripheral nervous system, this scenario is further complicated by the presence of peripherin, which appears around the same time 
Figure 1. $\alpha$-Internexin is an intermediate filament protein. $\alpha$-Internexin was purified from a Triton-insoluble, IF-enriched extract (lane $a$ ) by successive hydroxylapatite and DEAE chromatog(lane $b$ ) readily formed $10 \mathrm{~nm}$ filaments upon removal of the urea, as shown by electron microscopy, mag. $113,400 \times$ (lane $c)$. $\alpha$-Internexin $(I)$ appears in cytoskeletal extracts as a major band migrating below NF-L, with an apparent molecular weight of $66 \mathrm{kDa}$; other major bands in the extract include the proteins of the neurofilament triplet, NF-H $(H)$, NF-M $(M)$, and NF-L $(L)$, as well as glial filament protein, GFA $(G)$. raphy in $8 \mathrm{M}$ urea. The purified material
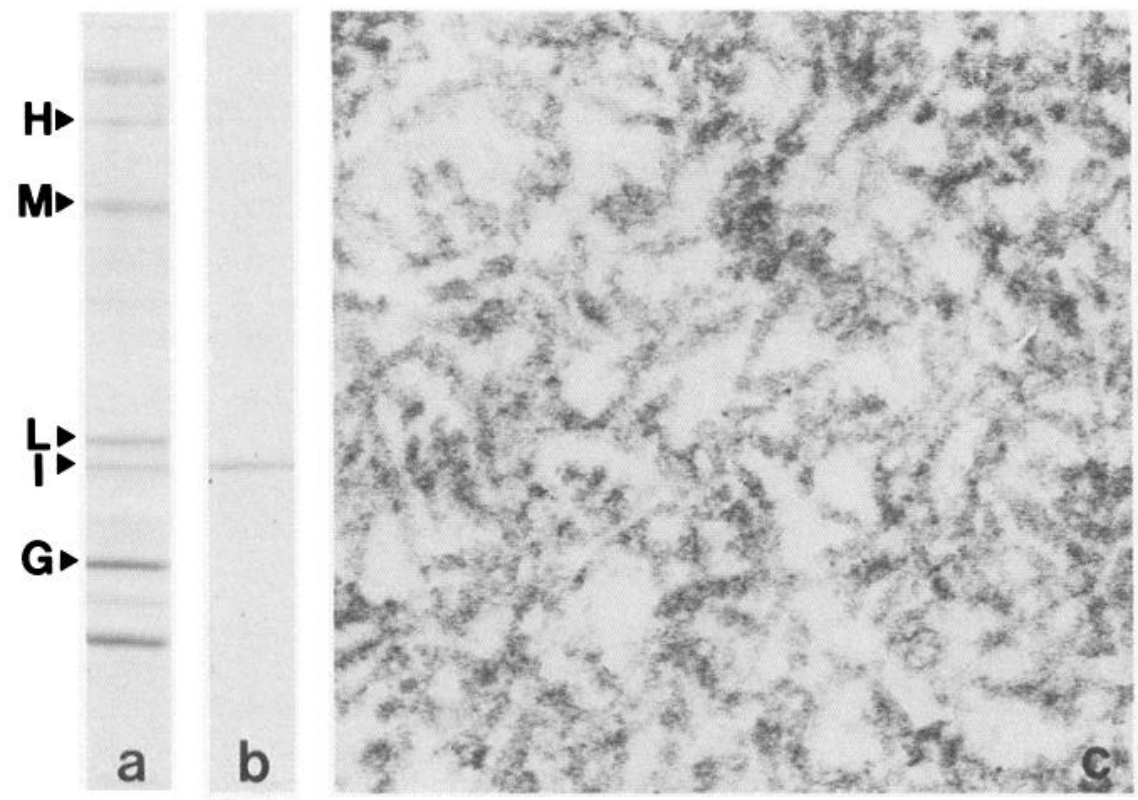

as NF-M in development (Troy et al., 1990). Unlike the neurofilament triplet proteins, however, peripherin is up-regulated following axotomy (Oblinger et al., 1989), suggesting some role for this protein in axon outgrowth.

Apparently, the concept of a "neurofilament triplet" in the central nervous system (CNS) may also stand in need of some revision. $\alpha$-Internexin is a $66 \mathrm{kDa}$ protein that copurifies with IFs from rat brain, spinal cord, and optic nerve (Pachter and Liem, 1985). Data presented here, including polymerization in vitro, distribution in vivo, and axonal transport, demonstrate that $\alpha$-internexin is a neuronal IF protein present in a wide range of mammalian species. These and other data, including sequence analysis of a cDNA clone, conducted in our laboratory (Fliegner et al., 1990) confirm the identity of $\alpha$-internexin and the "novel $66 \mathrm{kD}$ NF protein" described by Chiu et al. (1989). While the distribution of $\alpha$-internexin in the adult closely parallels that of the neurofilament triplet proteins, its distribution in the embryo is far more extensive, approaching adult patterns and levels of expression at an earlier age, around embryonic day 16 . Immunological and biochemical data presented here suggest that embryonic neuronal IFs contain a higher proportion of $\alpha$-internexin than their adult counterparts, and that the expression of $\alpha$-internexin precedes that of NF-L in most of the developing brain.

\section{Materials and Methods}

Dissection of embryos. Time-pregnant Sprague-Dawley rats (Charles River Breeding Laboratories, Wilmington, MA) were killed by $\mathrm{CO}_{2}$ narcosis at embryonic day 12 (E12), day 14 (E14), or day 16 (E16), and the embryos removed and frozen in a beaker of isopentane cooled in a slurry of dry ice and $95 \%$ ethanol, before storage at $-70^{\circ} \mathrm{C}$. Embryos utilized for cytoskeletal extraction were dissected further prior to freezing: brains were removed from E16 and E14 embryos, while for E12 embryos the entire cephalic region was used.

Cytoskeletal extraction. IF-enriched extracts were prepared from a wide range of starting materials, including adult rat brain; spinal cord; optic and sciatic nerves; E12, E14, and E16 embryonic rat brain; and adult mouse, cow, and chicken brain. Starting materials were homogenized in $\sim 10 \mathrm{vol}$ of solution A (10 mM phosphate, $1.0 \mathrm{~mm}$ EDTA, 0.1 $\mathrm{M} \mathrm{NaCl}, \mathrm{pH} 6.8$, with protease inhibitors $0.5 \mathrm{~mm}$ dithiothreitol, $10 \mu \mathrm{g} /$ $\mathrm{ml}$ leupeptin, $10 \mu \mathrm{g} / \mathrm{ml}$ tosyl arginyl methyl ester, and $1 \mu \mathrm{g} / \mathrm{ml}$ pepstatin
A) containing $0.85 \mathrm{~m}$ sucrose and $1.0 \%$ Triton X-100. Unless otherwise noted, inhibitors and reagents were obtained from the Sigma Chemical Co. (St. Louis, MO). Homogenates were incubated for $1 \mathrm{hr}$ on ice in the presence of $0.5 \mathrm{mg} / \mathrm{ml}$ DNAse I (Boehringer Mannheim, Indianapolis, IN) and centrifuged for $5 \mathrm{~min}$ at $10,000 \mathrm{rpm}$ to pellet the insoluble filaments. Pellets were washed twice by resuspension in $\sim 10 \mathrm{vol}$ of solution A followed by centrifugation as before. Final pellets were homogenized in approximately equal volumes of either deionized $8 \mathrm{M}$ urea or sample buffer $(0.0625 \mathrm{~mm}$ Tris buffer, $\mathrm{pH} 6.5,10 \%$ (vol $/ \mathrm{vol})$ glycerol, $1 \%$ (vol/vol) $\beta$-mercaptoethanol, $1 \%$ (vol/vol) sodium dodecyl sulfate, $0.1 \%$ bromophenol blue), and stored at $-20^{\circ} \mathrm{C}$.

Purification and reassembly of $\alpha$-internexin. $\alpha$-Internexin was purified from cytoskeletal extracts of rat spinal cord by successive hydroxylapatite and DEAE-cellulose chromatography in the presence of $8 \mathrm{~m}$ urea, as described previously (Pachter and Liem, 1985). For reassembly of purified $\alpha$-internexin, urea was removed by dialysis and insoluble material was pelleted by centrifugation at $100,000 \times g$ for $60 \mathrm{~min}$. Pellets were fixed in $1 \%$ glutaraldehyde, embedded in plastic resin, sectioned on a Sorvall MT5000 ultramicrotome, and stained with uranyl acetate and Reynold's lead citrate for conventional transmission electron microscopy (Reynolds, 1963). Sections were viewed on a JEOL 100C electron microscope operating at $80 \mathrm{kV}$.

Antibodies. Two monoclonal antibodies recognizing $\alpha$-internexin, $\mathrm{mAb} 135$ and $\mathrm{mAb} 233$, were obtained, according to the method of Kohler and Milstein (1976), from 2 separate fusions in the presence of polyethylene glycol (Gibco Laboratories, Grand Island, NY) of NS-1 mouse myeloma cells with spleen cells from Balb/c mice previously immunized with purified $\alpha$-internexin. Three subcutaneous injections of $\sim 50 \mu \mathrm{g} \alpha$-internexin, diluted 1:1 in Freund's complete adjuvant (Gibco), were administered at 4 week intervals, followed by a single peritoneal injection of $\sim 50 \mu \mathrm{g}$ purified $\alpha$-internexin in PBS $3 \mathrm{~d}$ before fusion. Cells were cultured in RPMI-1640 supplemented with $10 \%$ fetal calf serum and minimum essential medium (MEM) essential amino acids (Gibco); unfused NS-1 cells were eliminated by the presence of $1 \%$ aminopterin, $0.1 \mathrm{~mm}$ hypoxanthine, and $0.016 \mathrm{~mm}$ thymidine in the culture medium, and antibody-producing hybridomas were selected by Western blotting against purified $\alpha$-internexin (described below). Positive colonies were cloned by limiting dilution. A rabbit polyclonal antibody to NF-L was prepared against a synthetic, 22-amino-acid Nterminal peptide (NFL-N); as this peptide contains no known phosphorylation sites, the antibody should thus be independent of phosphorylation state (Chin et al., 1989). A rabbit polyclonal antibody to NF-M has been described previously (Pachter and Liem, 1984). Additional monoclonal antibodies to NF-L and NF-M were commercially obtained (Boehringer Mannheim, Indianapolis, IN). A rabbit polyclonal antibody to vimentin was generously provided by Dr. Eugenia Wang (Lady Davis Institute, Montreal).

One- and two-dimensional SDS-PAGE. Cytoskeletal extracts were 
subjected to 1-dimensional electrophoresis in the presence of SDS (Laemmli, 1970). Protein concentrations were estimated by Lowry determination, and from $\sim 10$ to $50 \mu \mathrm{g}$ of the cytoskeletal extracts was applied to each lane of a $7.5 \%$ vertical slab gel (Hoeffer Instruments, San Francisco, CA). Two-dimensional electrophoresis was performed essentially according to the method of O'Farrell (1975). For the first dimension, $\sim 50 \mu \mathrm{g}$ of samples was diluted in lysis buffer supplemented with $0.1 \%$ SDS and applied to polyacrylamide tube gels containing a $\mathrm{pH}$ gradient established by the addition of $1.6 \%(\mathrm{vol} / \mathrm{vol}) \mathrm{pH} 4-6 \mathrm{am}-$ pholines and $0.4 \% \mathrm{pH} 3.5-10$ ampholines (LKB Instruments, Bromma, Sweden). The second dimension consisted of a 7.5\% SDS-PAGE slab gel, as described above. Gels were either fixed in 10\% acetic acid, $50 \%$ methanol, and stained with Coomassie blue, or transferred to nitrocellulose for Western blotting.

Western blotting. Transfer was performed by a modification of methods previously described (Towbin et al., 1979). Gels were placed in contact with nitrocellulose in a buffer containing $19.2 \mathrm{~mm}$ glycine, 2.5 $\mathrm{mm}$ Tris, and $20 \%$ methanol $(\mathrm{vol} / \mathrm{vol})$ at a $\mathrm{pH}$ of 8.3 , and a constant current of $20 \mathrm{~mA}$ was applied overnight in a transfer apparatus (BioRad Instruments, Richmond, CA). Blots were then incubated for $2 \mathrm{hr}$ in blocking buffer (PBS containing 5\% nonfat dry milk) before incubation for $2 \mathrm{hr}$ with primary antibodies. Monoclonal and polyclonal antibodies to NF-L were used at dilutions of $1: 10$ and $1: 1000$, respectively. For the monoclonal antibodies to $\alpha$-internexin, culture supernatants were employed directly. Blots were then reacted with a streptavidin/biotin/horseradish peroxidase complex (Amersham Inc. Arlington Heights, IL) and visualized using diaminobenzidine and hydrogen peroxide.

Immunofluorescence on cryostat sections. Frozen rat brains and embryos were mounted in Tissue-Tek (Miles Laboratories) and $10 \mu \mathrm{m}$ sections were taken at $-20^{\circ} \mathrm{C}$ on a Reinhart cryostat (Bright Instrument Co., Huntington, England). Sagittal, coronal, and longitudinal sections were placed on gelatin-coated glass slides and allowed to air-dry before storage at $-70^{\circ} \mathrm{C}$. Sections were fixed for $15 \mathrm{~min}$ in cold methanol at $-20^{\circ} \mathrm{C}$ and rinsed 3 times in PBS prior to staining. Monoclonal antibodies to NF-L and NF-M were diluted 1:10 in PBS; rabbit polyclonal antibodies to NF-L, NF-M, and vimentin were employed at working dilutions of $1: 200,1: 100$, and $1: 100$, respectively, in PBS. In the case of mAb135 and mAb233, the monoclonal antibodies to $\alpha$-internexin, culture supernatants were employed directly. For double-labeling experiments, each of the rabbit antibodies was diluted directly in mAb135 or mAb233; the order of application of the antibodies did not appear to affect results. All primary antibodies were applied for $2 \mathrm{hr}$ at room temperature and then rinsed 5 times for $3 \mathrm{~min}$ with PBS. For the second antibody, fluorescein-conjugated goat anti-mouse IgG and rhodamineconjugated anti-rabbit IgG (Cappel Laboratories, Malvern, PA) were applied at 1:100 in PBS for $1 \mathrm{hr}$. After 5 more rinses in PBS, 1 drop of a mixture consisting of $30 \%$ glycerol $(\mathrm{vol} / \mathrm{vol})$ and $16 \%$ polyvinyl alcohol was added to each section, and coverslips were applied. Sections were viewed and photographed on an Optiphot fluorescence microscope (Nikon Instruments, Tokyo, Japan).

Axonal transport. Neonatal and young adult albino rats were anesthetized with methoxyflurane (Metofane, Pitman-Moore, Washington Crossing, NJ) and injected intraocularly with $100-250 \mu \mathrm{Ci}\left[{ }^{35} \mathrm{~S}\right]-$-methionine (NEN/DuPont, Wilmington, DE) using a Hamilton syringe fitted with a $32 \mathrm{G}$ needle. All injections were performed with the aid of a dissection microscope and a mechanical micromanipulator. Newborn pups required an incision to be made along the still fused eyelid borders. The needle was positioned for entry into the vitreous chamber at the posterior aspect of the scleral-corneal junction. Volumes up to $10 \mu \mathrm{l}$ were then slowly infused into the eye. After allowing sufficient time for transport of newly synthesized retinal ganglion cell proteins into the optic nerve, the animals were killed by $\mathrm{CO}_{2}$ narcosis and decapitation. The radiolabeled optic pathway was dissected out and the individual optic nerves and tracts were then carefully cut into $1 \mathrm{~mm}$ segments and homogenized. The Triton-soluble and insoluble fractions were prepared as previously described, an aliquot of each was placed in Aquasol liquid scintillation cocktail (NEN) and counted, and remaining samples were then subjected to 1- or 2-dimensional SDS-PAGE and fluorography.

\section{Results}

\section{Protein chemical and axonal transport studies}

The electrophoretic profile of the Triton-insoluble, IF-enriched extract from rat optic nerve is shown in Figure 1 (lane a), along
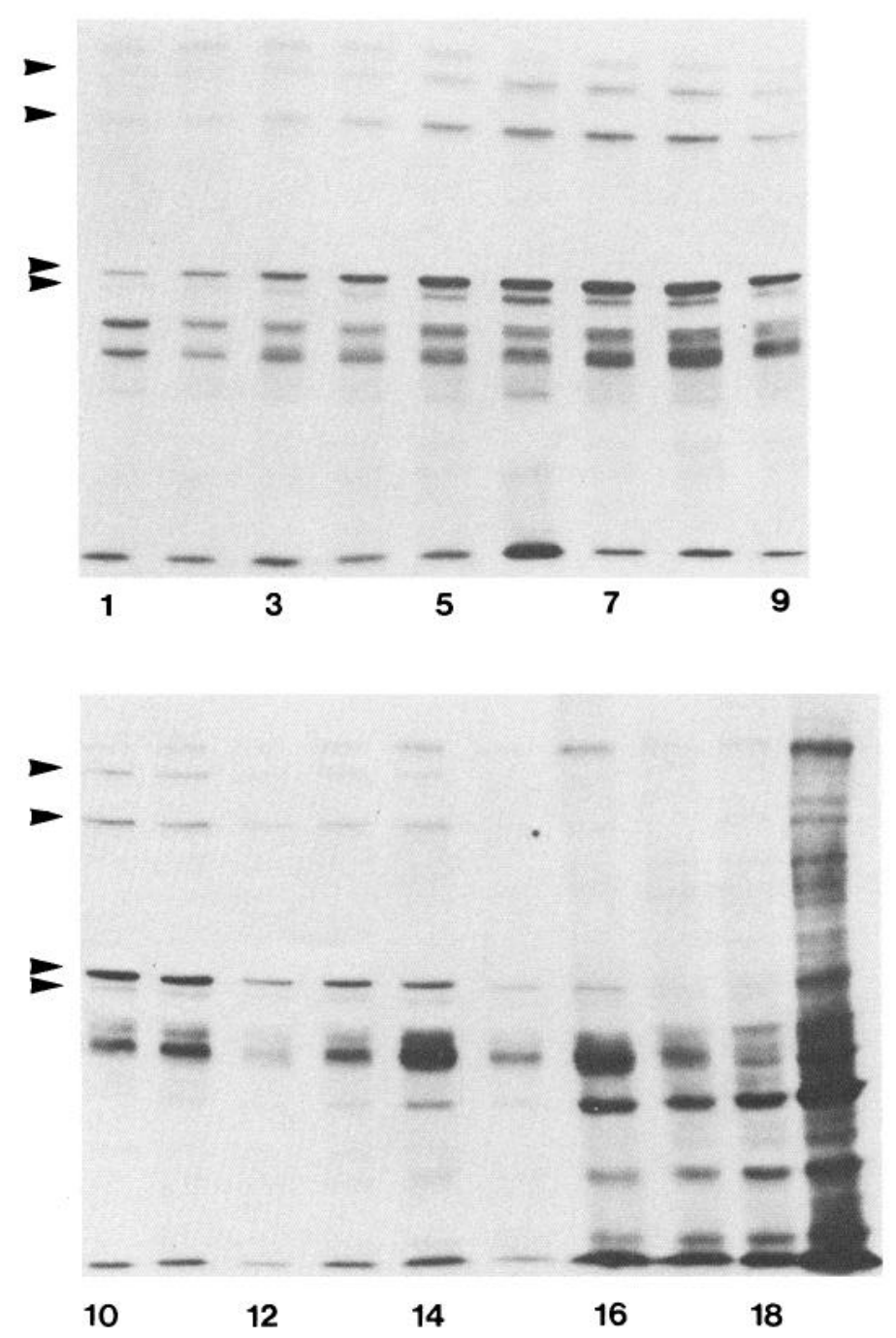

Figure 2. Slow axonal transport of $\alpha$-internexin in adult rat optic nerve. Thirty-two days following a single intraocular injection of $200 \mu \mathrm{Ci}\left[{ }^{35} \mathrm{~S}\right]-$ methionine, adult rats were killed and the optic nerves excised and cut into $1 \mathrm{~mm}$ segments, homogenized, separated by SDS-PAGE, and visualized by fluorography; gel lanes are numbered from the retinal end of the optic nerve toward the optic tract. $\alpha$-Internexin is clearly cotransported with the neurofilament triplet proteins as a major part of the SCa component of slow axonal transport. Positions of neuronal IFs are indicated by the arrowheads at left (from top): NF-H, NF-M, NF-L, $\alpha$-internexin.

with purified $\alpha$-internexin (lane $b$ ). The crude extract contains prominent bands representing NF-H, NF-M, NF-L, glial filament protein (GFA), and $\alpha$-internexin, which appears as a band migrating below NF-L. $\alpha$-Internexin was resolved from the extract by successive hydroxylapatite and DEAE-cellulose chromatography in $8 \mathrm{~m}$ urea. Upon removal of urea, the purified material readily formed $10 \mathrm{~nm}$ filaments, as shown by electron microscopy (lane c).

Axonal transport studies of adult rat optic nerve proteins (Fig. 2) clearly demonstrate that $\alpha$-internexin cotransports with the $\mathrm{NF}$ triplet proteins in slow component a $(\mathrm{SCa})$. The calculated velocity of approximately $0.4-0.5 \mathrm{~mm} / \mathrm{d}$ is in good agreement with previously reported values for SCa (Hoffman and Lasek, 1975). 
Figure 3. Characterization of anti-IF antibodies. SDS-PAGE gels of cytoskeletal extracts from rat optic nerve were either stained with Coomassie blue (lane $a$ ) or transferred to nitrocellulose and stained with monoclonal antibodies to $\alpha$-internexin (lanes $b$ and $c$ ), NF-L (lane $d$ ), or NF-M (lane f). Also shown is a polyclonal antibody to NF-L, NFL-N (lane e), which was prepared against a synthetic $\mathrm{N}$-terminal peptide as described in text. The antibody to $\alpha$-internexin occasionally recognized a minor band of $\sim 145 \mathrm{kDa}$. To show that this band does not represent NF-M, purified neurofilament triplet (lane g) was transferred to nitrocellulose and stained with mAb135 (lane h); no activity was observed.
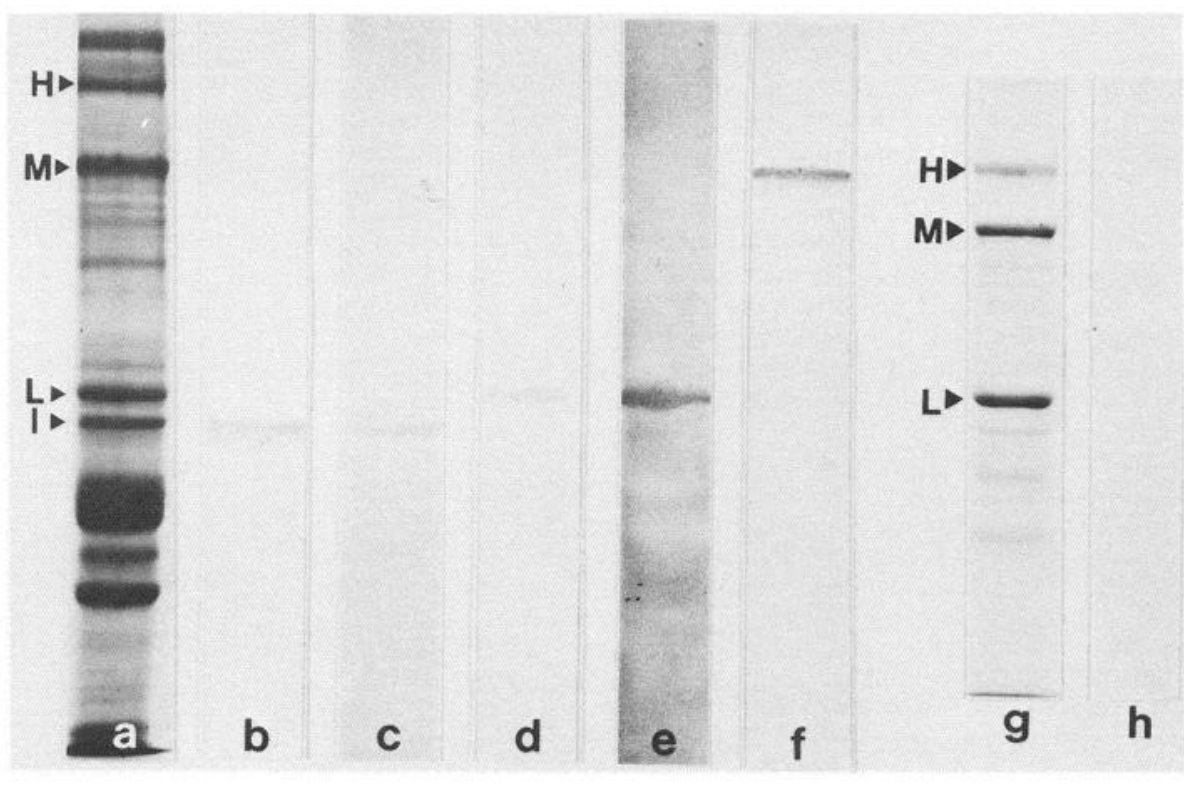

\section{Antibody preparation and characterization}

Using $\alpha$-internexin purified from rat spinal cord, we prepared 2 monoclonal antibody-producing cell lines, clones mAb135 and $\mathrm{mAb} 233$; the antibodies are highly specific for $\alpha$-internexin, with no observed activity to the other NF proteins, as shown by Western blots against cytoskeletal extracts from rat optic nerve (Fig. 3, lanes $b, c$ ). Both antibodies occasionally recognized a minor band of apparent molecular weight $\sim 145 \mathrm{kDa}$. To confirm that this band was not NF-M, mAb135 was blotted against purified neurofilament triplet (lane $h$ ); no activity was observed. Based on its comigration with an $\alpha$-internexin dimer obtained by chemical cross-linking, as described by Quinlan and Franke (1982), we presently consider this band to be a dimer of $\alpha$-internexin. Additionally, smaller bands of lower intensity were observed in Western blots against some of the extracts; their number and intensity could be increased by repeated freezing and thawing of the extracts, suggesting that they represent breakdown products of $\alpha$-internexin. Neither of the 2 monoclonal antibodies to $\alpha$-internexin displayed any activity against the nonneuronal IF proteins, GFA and vimentin, either by Western blotting or by immunofluorescence against cultured fibroblasts and glioma cells, confirming that the minor, lower molecular weight bands do not represent these other IF proteins. Also shown in Figure 3 are monoclonal and polyclonal antibodies to NF-L and NF-M used in this study (lanes $d-f$ ).

Unlike antibodies to the neurofilament triplet proteins, which worked equally well against extracts from central or peripheral
Figure 4. $\alpha$-Internexin is found in other mammalian species. SDS-PAGE gels of CNS cytoskeletal extracts from rat (lane 1), mouse (lane 2), cow (lane $3)$, and chicken (lane 4) were either stained with Coomassie blue $(A)$, or transferred to nitrocellulose and blotted with $\mathrm{mAb} 135$, a monoclonal antibody against $\alpha$-internexin $(B)$. The antibody recognized major bands in all 3 mammalian species we examined; the avian cytoskeleton, as represented here by the chicken, does not show a cross-reactive protein. The position of $\alpha$-internexin is given by the arrowheads; apparent molecular weights ranged from $\sim 59 \mathrm{kDa}$ in the mouse to $\sim 70 \mathrm{kDa}$ in the cow.

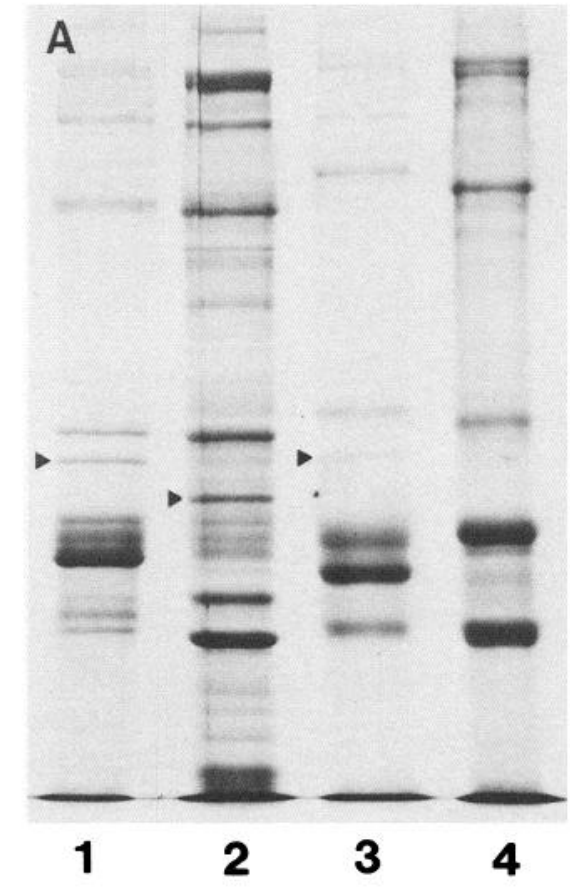

B

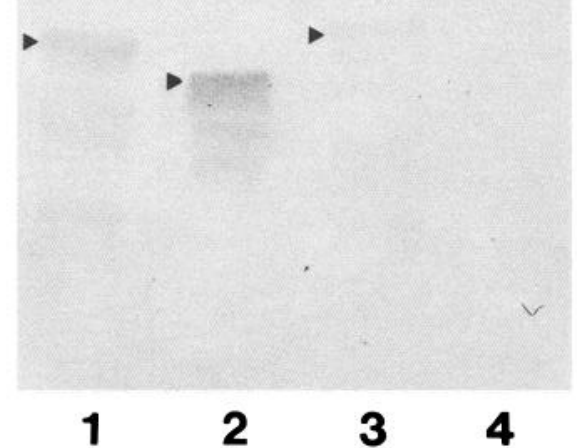



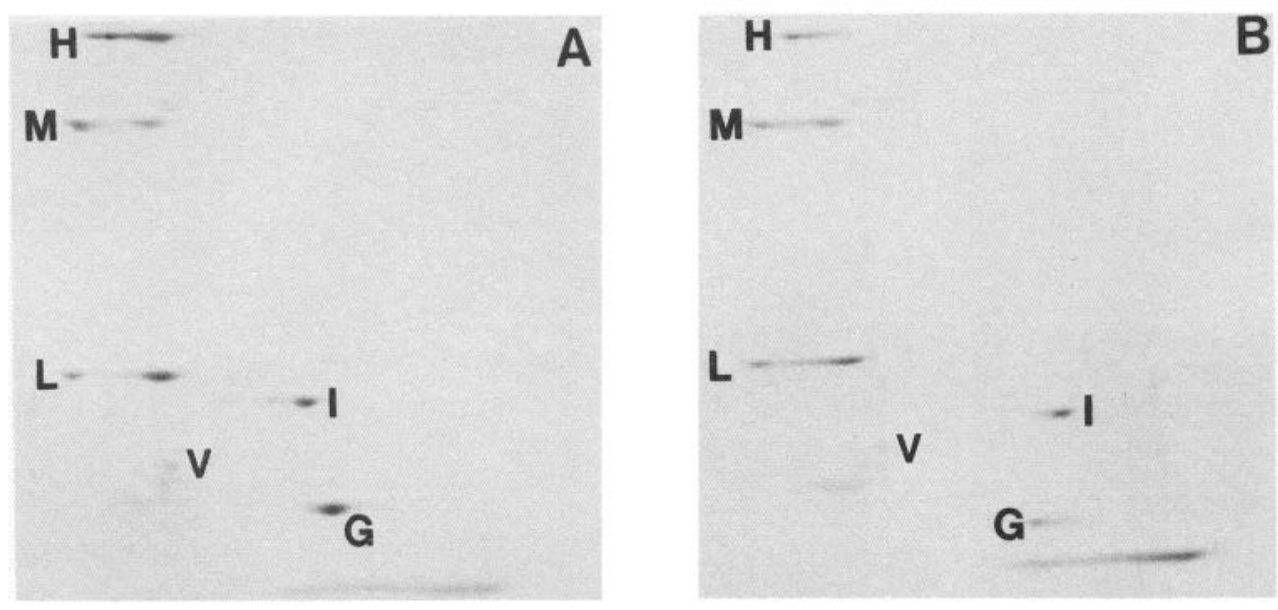

Figure 5. Two-dimensional gel analysis of rat and mouse $\alpha$-internexin. Rat and mouse cytoskeletal extracts were subjected to isoelectric focusing followed by SDS-PAGE and stained with Coomassie blue. In the rat, shown at left $(A), \alpha$-internexin displays an isoelectric point of $\sim 5.8$, with a somewhat more basic value and lower molecular weight in the mouse $(B)$. Other major bands include NF-H $(H)$, NF-M $(M)$, NF-L $(L)$, vimentin $(V)$, and GFA $(G)$. sources, antibodies to $\alpha$-internexin displayed comparatively little activity when cytoskeletal extracts of adult rat sciatic nerve were employed for Western blotting (not shown).

CNS cytoskeletal preparations from other mammalian species displayed similar electrophoretic profiles. In mouse, rat, and cow brain extracts (Fig. $4 A$, lanes $1-3$ ) the 3 neurofilament proteins and GFA are easily identified, along with an additional major band migrating below NF-L which was recognized by the monoclonal antibody to rat $\alpha$-internexin (Fig. $4 B$ ). The apparent molecular weight of this band ranged from $\sim 59 \mathrm{kDa}$ in mouse to $\sim 70 \mathrm{kDa}$ in cow brain extracts. No comparable reactive protein was found in chicken, the only nonmammalian species we examined (lane 4). Reactivity was also shown against a cytoskeletal preparation obtained from human brain, but this material was highly degraded owing to the long postmortem period. The highest molecular weight band corresponded to a protein of $\sim 65 \mathrm{kDa}$.

Two-dimensional gel analysis of rat and mouse cytoskeletalenriched extracts from CNS is shown in Figure 5. In the rat $(A)$, $\alpha$-internexin has an observed isoelectric point of $\sim 5.8$, with one additional minor, more acidic isovariant. Other major bands include NF-H, NF-M, NF-L, vimentin, and GFA. Murine $\alpha$-internexin has a lower molecular weight and somewhat higher isoelectric point; these data also show that murine $\alpha$-internexin has a higher pI than vimentin, although its molecular weight is closer to vimentin than in the rat.

\section{Expression in the adult CNS}

In the adult CNS, the distribution of $\alpha$-internexin as given by indirect immunofluorescence on cryostat sections closely parallels that of NF-L and NF-M. Intense, virtually indistinguishable patterns of axonal staining for all 3 proteins were observed at all levels of the neocortex and underlying white matter (not shown). Significant differences were apparent in the brain stem and cerebellum, however. In the cerebellum (Fig. 6, $A, B$ ), all 3 proteins were found in the fibers of the medullary layer, some of which were identified as the axons of Purkinje cells. Also stained were the axons of basket cells, terminating in axosomatic "nets" enshrouding the Purkinje cell bodies, which did not stain. No staining of the numerous cell bodies of the granular layer was observed. Antibodies to all 3 proteins stained numerous medium- and large-caliber axons in the granular and molecular layers. One class of small-caliber axons, apparently originating in the granule cell layer, stained intensely for $\alpha$-internexin but were negative for NF-L and NF-M. These appear to be the parallel fibers, which project radially to the molecular layer, where they can be seen to bifurcate and run parallel to the surface of the cerebellar folia. This is in agreement with the findings of Chiu et al. (1989), who have shown that their antibody to the " $66 \mathrm{kD}$ protein" stains parallel fibers in the adult cerebellum. In the brain stem, levels and patterns of staining for $\alpha$-internexin were generally lower and less widespread. The spinal tract of the trigeminal nerve is shown as an example of one of numerous tracts in the medulla that stain strongly for NF-L or NF-M (Fig. $6 D$ ) but only faintly for $\alpha$-internexin (Fig. 6C).

\section{Developmental studies}

Neurofilament-enriched cytoskeletal preparations from E12, E14, E16, and adult rat CNS were resolved by SDS-PAGE and either stained with Coomassie blue or transferred to nitrocellulose for Western blotting with antibodies to $\alpha$-internexin or NF-L (Fig. 7). $\alpha$-Internexin can easily be visualized at all ages shown by Coomassie blue $(A)$ or Western blotting $(B)$. NF-L can be seen only in the adult homogenate when Coomassie blue is used and is difficult to detect before E16 by Western blotting $(C)$. Similar results were obtained using both monoclonal antibodies against $\alpha$-internexin and both monoclonal and polyclonal antibodies to NF-L. A major band migrating just below NF-L can be seen in the Coomassie-stained cytoskeletal extracts; this band cannot be NF-L, as can be seen by comparing the strong Coomassiestained band in Figure $7 \mathrm{~A}$ (lane 2) with the lack of staining in Figure $7 C$ (lane 2 ) by the monoclonal antibody to NF-L, whose activity is independent of degree of phosphorylation (Shaw et al., 1986). When cytoskeletal extracts were subjected to 2-dimensional gel electrophoresis (not shown), this additional band resolved into 2 spots which were not recognized by antibodies to NF-L or $\alpha$-internexin and were clearly distinguishable from NF-L (which appeared as a single spot with a somewhat lower isoelectric point). Also notable is the absence of GFA from any of the embryonic extracts, and the associated peak in vimentin expression at E16, reflecting the fact that vimentin, and not GFA, is the prevalent IF in immature glia (Dahl et al., 1981).

An investigation of axonal transport in the neonate is shown in Figure 8. Twenty-four hours following intraocular injection of $\left[{ }^{35} \mathrm{~S}\right]$-methionine, the optic nerves of newborn rats were dissected out, cut into proximal and distal sections (relative to the retina), and the radiolabeled, Triton-insoluble cytoskeletal proteins were extracted and subjected to 2-dimensional SDS-PAGE 

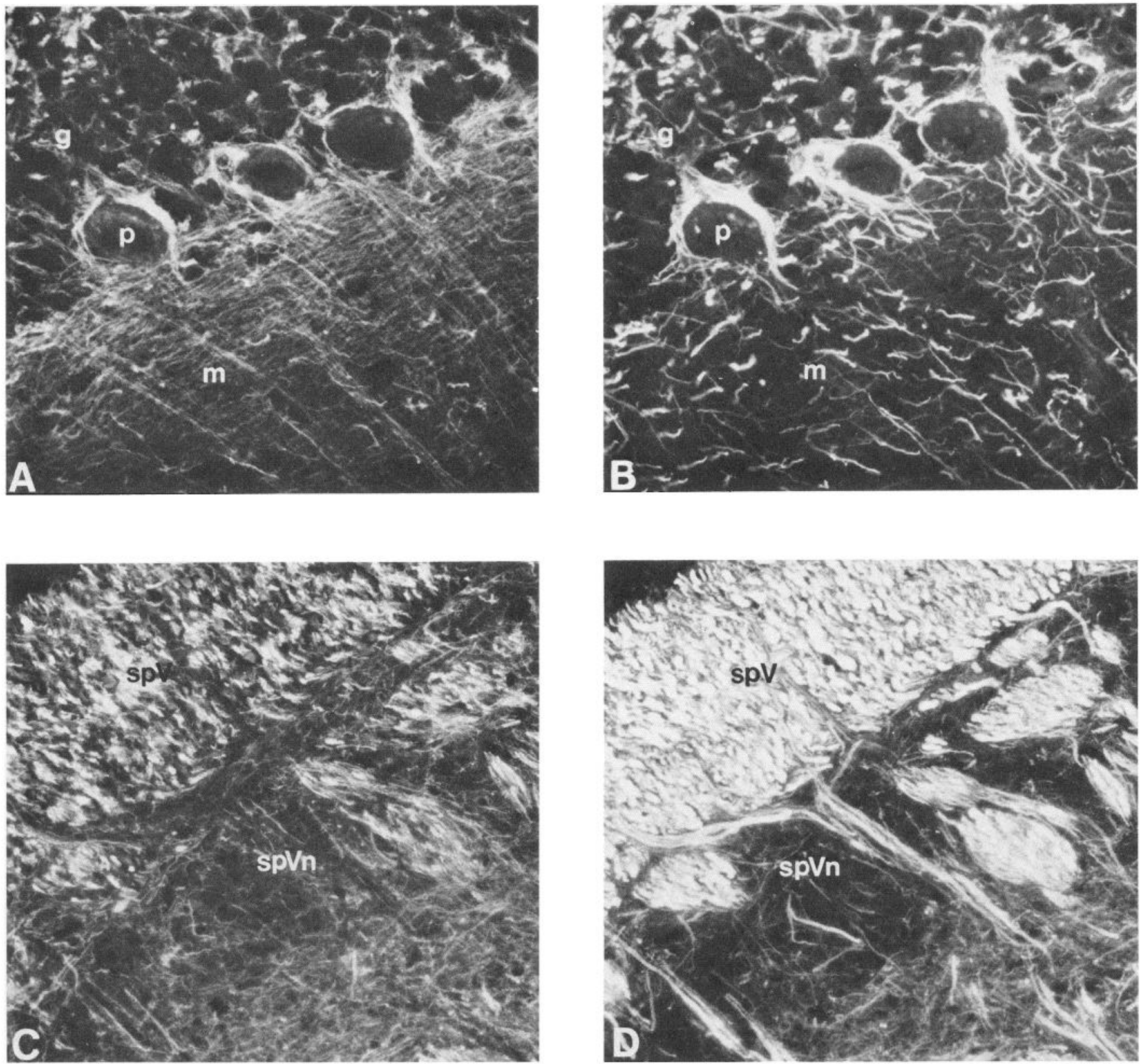

Figure 6. Expression of $\alpha$-internexin and NF-M in adult rat brain. Indirect immunofluorescence was performed on coronal sections of cerebellum $(A, B)$ and midmedulla $(C, D)$. Sections were double-labeled with a mixture of mAb135, a monoclonal antibody to $\alpha$-internexin, and a rabbit polyclonal antibody to the middle neurofilament subunit, NF-M; the distribution of $\alpha$-internexin is shown in $A$ and $C$, while that of NF-M is shown in $B$ and $D$. In the cerebellum, staining for both proteins can be seen in the basket cell fibers enshrouding the 3 Purkinje cells shown. Numerous axons in the granular and molecular layers stained with both antibodies, although staining for NF-M was considerably more intense. Conversely, the numerous parallel fibers in the molecular layer exhibit strong staining for $\alpha$-internexin and little or no staining for NF-M. In the medulla, the spinal tract of the trigeminal nucleus was one of numerous tracts exhibiting strong staining for NF-M $(D)$ and little or no staining for $\alpha$-internexin (C). Other structures, such as the pyramidal tracts, stained for both proteins (not shown). $g=$ granular cell layer; $p=$ Purkinje cell layer, $m=$ molecular layer; $s p V=$ spinal tract of trigeminal nucleus; $S p V n=$ spinal trigeminal nucleus. Mag. $=720 \times(A, B) ; 360 \times(C, D)$.

followed by fluorography, as described above. $\alpha$-Internexin and NF-L are already localized in the distal half of the optic nerve $(B)$, indicating a velocity for these proteins of $\sim 5.0 \mathrm{~mm} / \mathrm{d}$, about 10 times faster than their observed velocity in the adult (Fig. 2 ). This is in agreement with previous reports that axonal transport of the cytoskeletal proteins slows as development progresses (Hendrickson and Cowan, 1971; Willard and Simon, 1983). The finding that $\alpha$-internexin and NF-L are transported at similar rates, both in the adult and in the neonate, suggests their close association as part of the same intermediate filament network.

The same dilutions of antibodies to $\alpha$-internexin and NF-L which yield comparable patterns and levels of staining in the adult produce widely dissimilar results on sections taken from E12 or E16 embryos. A coronal section from an E16 embryo taken at the level of the olfactory cortex is shown in Figure 9. 

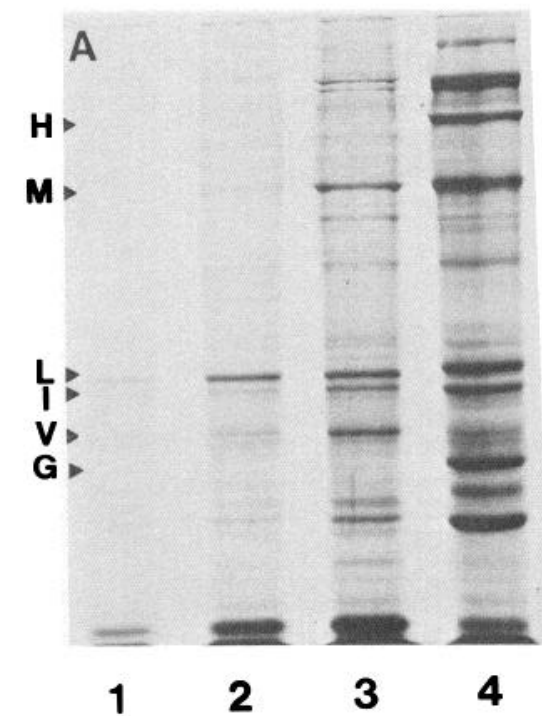

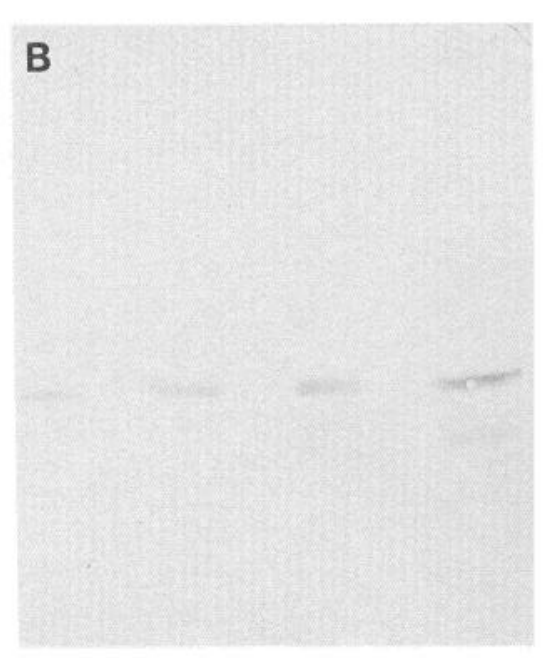

$1 \quad 2 \quad 3 \quad 4$

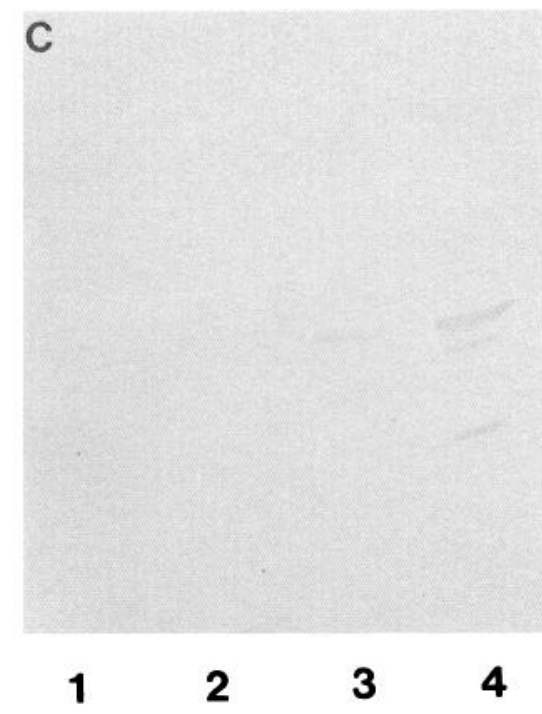

Figure 7. SDS-PAGE analysis of cytoskeletal extracts from developing brain. Rat CNS cytoskeletal extracts from E12 (lane 1), E14 (lane 2), E16 (lane 3), and adult (lane 4) were either stained with Coomassie blue ( $A$, at left), or transferred to nitrocellulose and blotted with monoclonal antibodies to $\alpha$-internexin $(B)$ or NF-L $(C)$. $\alpha$-Internexin $(I)$ can be observed at all ages we examined, but NF-L $(L)$ is present in significant quantities only by E16. A band migrating slightly ahead of NF-L can be observed, which does not react with the monoclonal antibody against NF-L. The positions of the other major bands, NF-H $(H)$, NF-M $(M)$, vimentin $(V)$, and GFA $(G)$, are indicated at left.

Extensive staining for $\alpha$-internexin can be seen in the fibers innervating the concentric layers of the olfactory cortex $(A)$, which still contain little, if any, NF-L $(B)$. Conversely, strong staining for both proteins can be seen in the cranial nerve indicated by the arrows. The unstained shadows of numerous cell bodies can also be observed, in various stages of their migration from the germinal zone bordering the olfactory ventricle to form the lamina of the olfactory cortex. No staining of migrating cells in the intermediate zone was observed (for review of terminology of the developing nervous system, see Boulder Committee, 1970). Moving caudally, a coronal section through the anterior cortex is shown in Figure $9(C, D)$. Both $\alpha$-internexin and NF-L are present in the cranial nerve indicated by the arrow, while just inside the cranium $(\mathrm{cr})$, only $\alpha$-internexin can be detected in the lateral olfactory tract (olt), which can be seen running along the inner ventrolateral surface of the cortex.

Continuing to move caudally, sections of cerebral cortex at the level of the thalamus are shown in Figure 10. Strong staining for $\alpha$-internexin $(A, C)$ is evident in the fibers underlying the developing cortical plate $(c p)$, which do not stain for vimentin $(B)$ and stain only weakly for NF-L $(D)$. Composed of projections from the thalamus [and possibly, to a lesser extent, of subplate "pioneer neurons" (McConnell et al., 1989)], this welldefined layer stains strongly for $\alpha$-internexin at all levels of the cortex. $\alpha$-Internexin can also be seen in numerous radial fibers spanning the cortical plate (i.e., perpendicular to the thalamocortical fibers). These fibers, which do not stain for NF-L, do not appear to enter the intermediate zone, in contrast to the radial glial cells staining with vimentin $(B)$, which always extend from the ventricle to the pial surface. They may represent fibers of newly arrived neurons undergoing differentiation on the inner edge of the cortical plate, ultimately forming layers V and VI (the innermost layers of the mature cortex). In some sections, faint staining for $\alpha$-internexin was also observed on the outer edge of the cortical plate; these could be the horizontal fibers of the Cajal-Retzius cells of layer I, reportedly among the first to develop in the cortex (Ramon y Cajal, 1891; Retzius, 1893; Raedler and Sievers, 1976), an exception to the general "insideout" rule of cortical development (Angevine and Sidman, 1961; Berry and Rogers, 1965; Hicks and D'Amato, 1968). These radial and horizontal cortical processes staining with $\alpha$-internexin were most easily seen in midcortical sections passing through the thalamus; they were not observed in the anterior cortex, where staining was limited to the thalamocortical fiber layer (not shown).

Antibodies to both $\alpha$-internexin and NF-L stained the optic chiasm, optic nerves, and the ganglion cell layer of E16 retina (Fig. 11). Numerous radial fibers spanning the outer layers of the retina stained only for $\alpha$-internexin (Fig. 11C). Staining for $\alpha$-internexin in the absence of NF-L was also observed throughout the hypothalamus, septal nuclei, and much of the thalamus (not shown).

In the E12 embryos, both $\alpha$-internexin and NF-L were observed in the outermost layer of the neural tube from the spinal cord to the myelencephalon (Fig. 12, $C-F$ ). Antibodies to both proteins stained the developing dorsal and ventral roots $(E, F)$, and also the sympathetic ganglia (not shown). While the 2 proteins displayed similar patterns of distribution in the myelencephalon $(C, D)$, strong staining for $\alpha$-internexin extended further anterior to the level of the prospective midbrain, which showed comparatively little staining for NF-L $(A, B)$. No neuronal intermediate filament proteins were detectable in prospective forebrain at this stage.

The dilutions employed were arrived at after a series of experiments utilizing a wide range of conditions. Antibodies to NF-L were used at the highest concentrations that would not produce nonspecific staining. Dilutions were chosen so that staining for NF-L would be greater than or equal to that observed with the antibodies to $\alpha$-internexin throughout most of the adult CNS. To control for possible competitive effects, double-labeled sections were compared with adjacent sections. All of these results were confirmed in separate experiments, using 

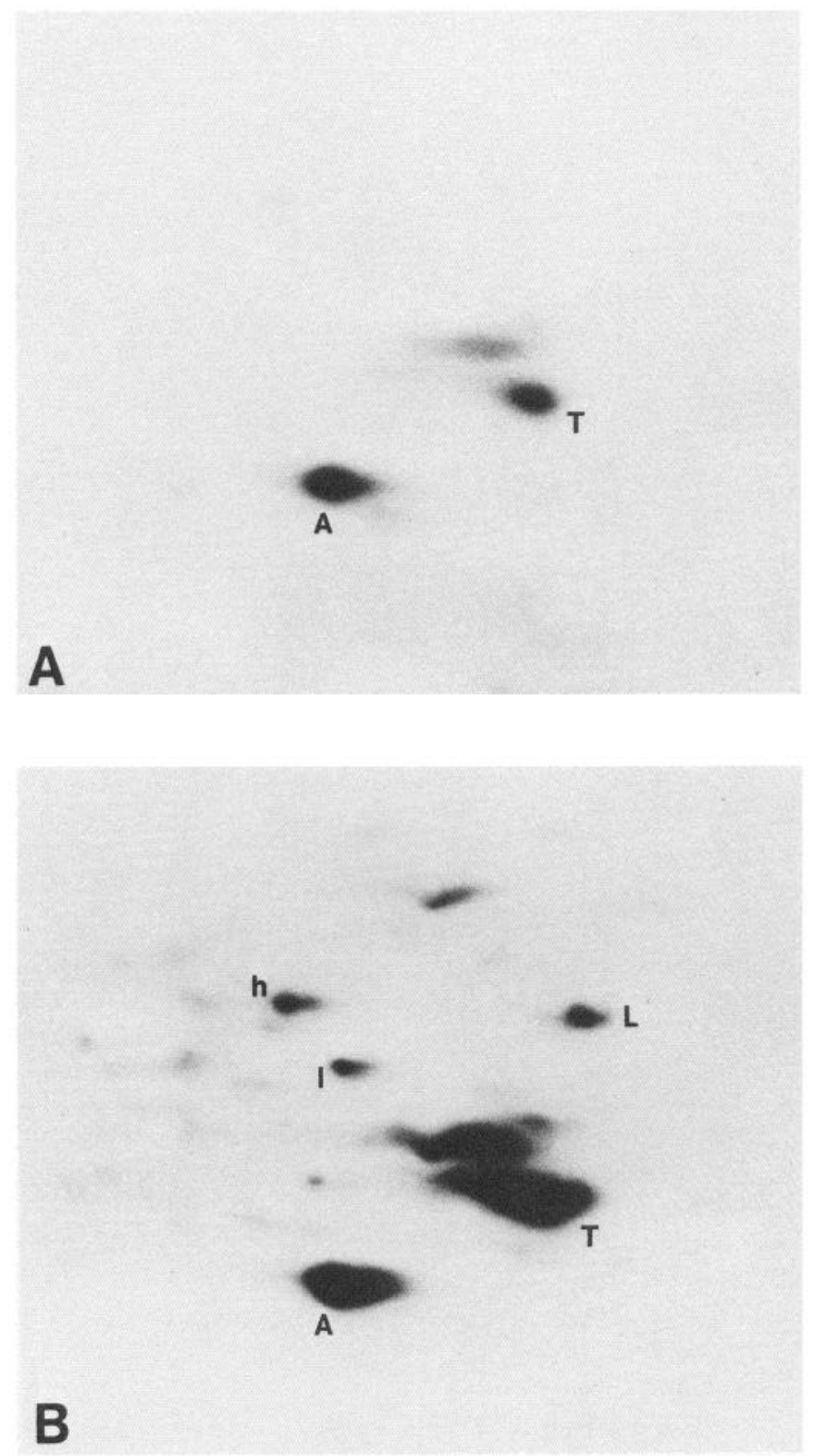

Figure 8. Axonal transport of NF proteins in developing optic nerve. Twenty-four hours following intraocular injection of $100 \mu \mathrm{Ci}$ of $\left[{ }^{35} \mathrm{~S}\right]-$ methionine into the vitreous chamber, 1-d-old rat pups were killed, and the optic nerves were removed, cut into proximal and distal portions (relative to the retina), homogenized, separated by 2-dimensional SDSPAGE, and visualized by fluorography. The upper fluorograph shows proteins from the proximal half $(A)$, while the proteins in the distal half are shown below $(B) . L=\mathrm{NF}-\mathrm{L} ; T=$ tubulin; $A=$ actin; $h=\mathrm{hsc70}$; and $I=\alpha$-internexin.

$\mathrm{mAb} 233$ for $\alpha$-internexin and the Boehringer-Mannheim monoclonal antibody for NF-L.

\section{Discussion}

$\alpha$-Internexin is a $66 \mathrm{kDa}$ protein originally purified from rat brain and optic nerve (Pachter and Liem, 1985). Data presented here, including axonal transport, distribution in vivo, and polymerization in vitro to form $10 \mathrm{~nm}$ filaments, demonstrate that $\alpha$-internexin is a novel neuronal IF protein found in a wide range of mammalian species. In the adult CNS, $\alpha$-internexin exhibits a primarily axonal pattern of distribution similar to that of the other NF proteins. In the embryo, however, $\alpha$-internexin is much more abundant, appearing to approach adult patterns and levels of expression at an earlier age. The potential significance of this novel neuronal IF subunit in the adult, and of these changes in neuronal IF composition in the embryo, is discussed below.

$\alpha$-Internexin is almost certainly identical to the "novel $66 \mathrm{kD}$ neurofilament protein" recently described by Chiu et al. (1989). Their claim to the contrary is based largely on the fact that our initial attempts at polymerization in vitro of $\alpha$-internexin were unsuccessful, leading to its initial classification not as an IF, but as an IF-associated protein; successful polymerization in the present study (Fig. 1, lane c) resolves this discrepancy, which we attribute to improvements in the speed and efficiency of our purification scheme. Also mentioned in support of the nonidentity of the 2 proteins is the difference in reported values for the isoelectric point, with their value of 5.4 versus our reported value of $\sim 5.8$ (both in our original publication and in the present work). However, in either case the protein in question has a pI similar to that of actin, suggesting that the difference in reported values is due to differences between our respective gel systems. Finally, the distribution of $\alpha$-internexin in the adult rat CNS is the same as that reported for the $66 \mathrm{kDa}$ protein.

Sequence analysis of $\alpha$-internexin recently performed in our laboratory using a cDNA clone (Fliegner et al., 1990) confirms the identity of the 2 proteins: the 20 -amino-acid fragment published by Chiu et al. (1989) matches our sequence, and the observed amino acid composition of the $66 \mathrm{kDa}$ protein is nearly identical to the values calculated from our sequence data. Sequence analysis also confirms the classification of $\alpha$-internexin as an IF. The sequence conforms to the general structure of an IF, with the highest degree of homology to NF-M ( 46\%).

Does $\alpha$-internexin form an independent system of neuronal intermediate filaments, or does it copolymerize in vivo with the proteins of the neurofilament triplet? While this question cannot be resolved directly using the methods employed here, several lines of evidence suggest that the neuronal IF proteins form a single network. First, $\alpha$-internexin contains the $\alpha$-helical domain common to all IFs, which forms the core of the filament and presumably is responsible for polymerization. Second, in every case where the coexpression in the same cell of different IF proteins (other than the keratins) has been investigated, they have always been found to be copolymerized in a single network. Examples include NF-L or NF-M and vimentin in transfected fibroblasts (Chin and Liem, 1989; Monteiro and Cleveland, 1989), vimentin and GFA in glioma cells (Wang et al., 1984), and, of course, the 3 neurofilament triplet proteins in neurons (Willard and Simon, 1981). A close association between $\alpha$-internexin and the neurofilament triplet is further suggested by the axonal transport data, both in the adult and at postnatal day 7 (Figs. 2 and 8, respectively), in which $\alpha$-internexin and NF-L display similar migration rates. Similar results were also described by Monaco et al. (1985) for a $64 \mathrm{kDa}$ protein that was transported with the neurofilament triplet proteins in the adult optic nerve and had the same mobility as $\alpha$-internexin on 2-dimensional gels. The axonal transport of this protein was selectively accelerated along with that of the neurofilament triplet in rats treated with 2,5-hexanedione.

This close association is also in evidence in the almost inevitable appearance of $\alpha$-internexin as a major band in neuronal IF preparations from diverse sources (Dahl et al., 1981; Shaw 

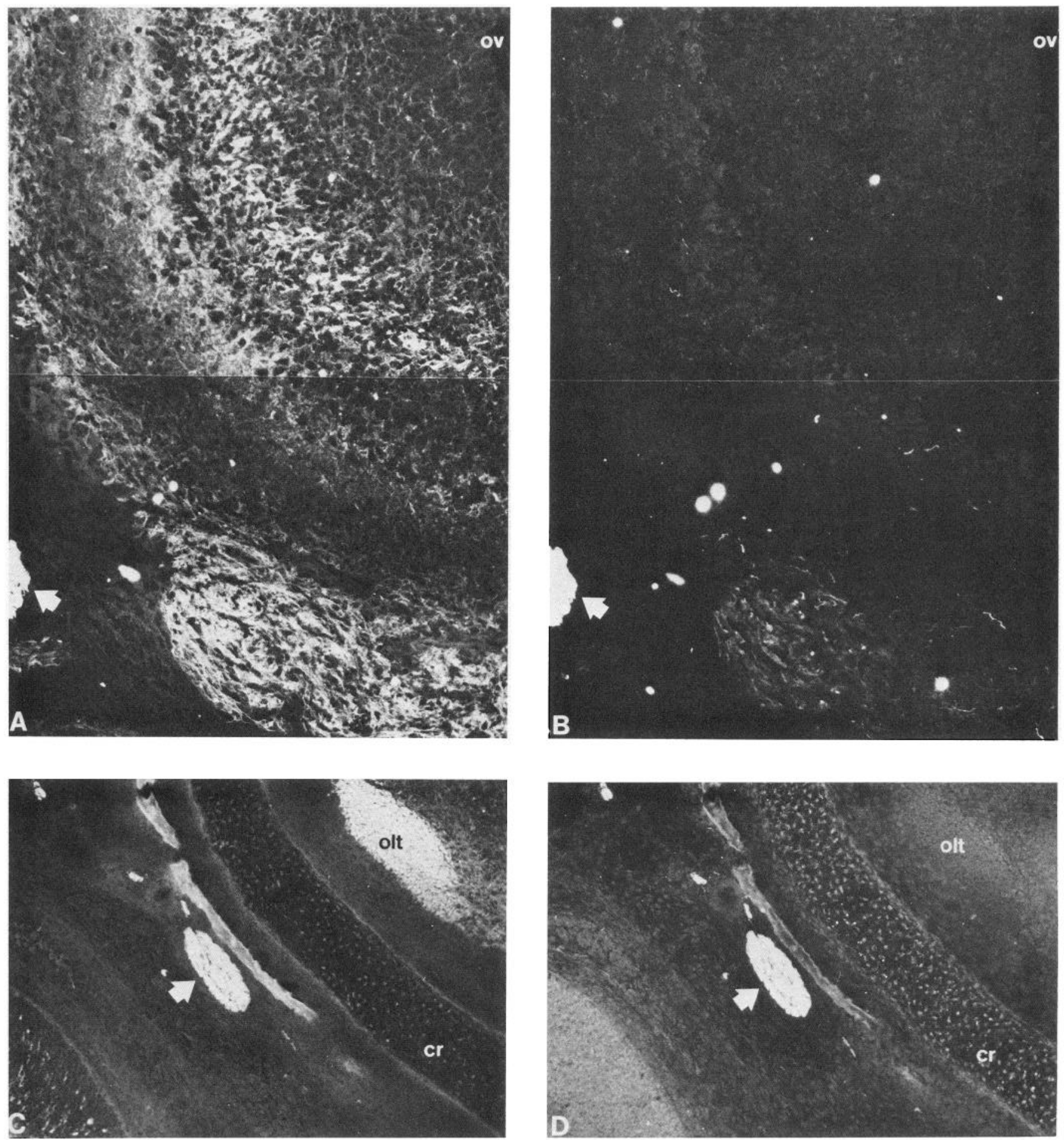

Figure 9. Early expression of $\alpha$-internexin in developing brain: olfactory system. Indirect immunofluorescence was performed on coronal sections of E16 rat brain using mAb135, a monoclonal antibody to $\alpha$-internexin $(A, C)$, and a polyclonal rabbit antibody to NF-L (B, $D$ ). Double labeling of $\alpha$-internexin and NF-L was accomplished through the use of fluorescein- and rhodamine-conjugated second antibodies, respectively. In the top 2 figures, extensive staining for $\alpha$-internexin can be seen in the fibers innervating the concentric layers of the olfactory cortex $(A)$, which still contain little if any NF-L $(B)$. Conversely, strong staining for both proteins can be seen in the cranial nerve, indicated by the arrow. The unstained shadows of numerous nuclei can also be observed, in various stages of their migration from the germinal zone bordering the olfactory ventricle (ov) to form the lamina of the olfactory cortex. In the 2 figures at bottom, early expression of $\alpha$-internexin is seen in the lateral olfactory tract (olt), which does not stain for NF-L $(D)$. In contrast, the cranial nerve indicated by the arrow stains strongly for both proteins. The optic vesicle can be seen in the lower left corner of panels $C$ and $D$; radial fibers spanning its width stained for $\alpha$-internexin only (see also Fig. 12). $c r=\mathrm{cranium}$. Mag. $=270 \times$. 

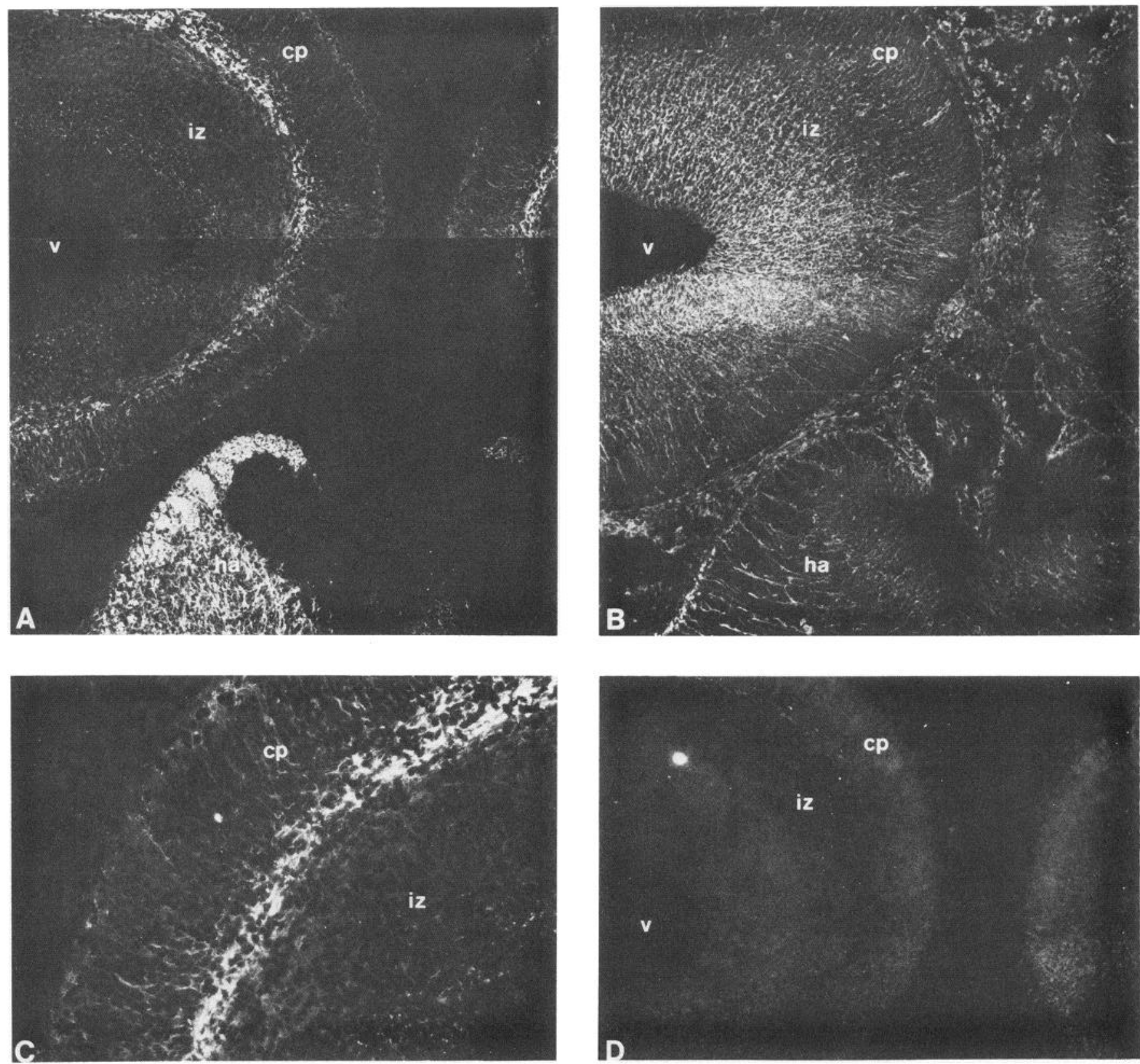

Figure 10. Early expression of $\alpha$-internexin in developing brain: cerebral cortex. Indirect immunofluorescence was performed on E16 rat brain sections as described above, using antibodies to $\alpha$-internexin $(A, C)$, vimentin $(B)$, and NF-L $(D) . A-C$ show the same section viewed by double labeling, while $D$ shows a section taken somewhat more caudally. Strong staining for $\alpha$-internexin is evident in the fibers underlying the developing cortical plate, which do not stain for vimentin and stain only weakly for NF-L. Expression of $\alpha$-internexin is also seen in the habenula (ha), and in numerous radial fibers spanning the cortical plate. These fibers do not appear to enter the intermediate zone ( $i z)$, in contrast to the radial fibers staining with vimentin, which extend from the ventricle $(V)$, to the pial surface. Mag. $=270 \times(A, B, D) ; 540 \times(C)$.

and Weber, 1982). This raises the question of why this major component of the neuronal cytoskeleton has not been previously identified. One reason for this is its ease of degradation (see Fig. 4), also reported by Chiu et al. for their $66 \mathrm{kDa}$ protein (1989). A second is the possibility that this protein represented a breakdown of NF-L, since it always migrates ahead of NF-L in 1-dimensional SDS-PAGE. Finally, the molecular weight of $\alpha$-internexin, $\sim 59 \mathrm{kDa}$ in the mouse, allows it to be mistaken for either vimentin or tubulin on 1-dimensional gels; these possibilities are discounted in the present study by both Western blotting and 2-dimensional gel analysis.
The absence of an immunoreactive band in the sample obtained from chick optic nerve does not preclude the possibility that $\alpha$-internexin may be present in nonmammalian species. Many antibodies to mammalian IFs do not recognize their avian counterpart and it is therefore possible that our 2 monoclonal antibodies similarly fail to recognize chick $\alpha$-internexin. A protein of similar molecular weight, NAPA-73, has been described in chick as a neurofilament-associated protein, which migrates behind NF-L and is associated with the stage of terminal differentiation of chick brain neurons (Ciment et al., 1986; Wu and de Vellis, 1987). Comparisons and homologies between 

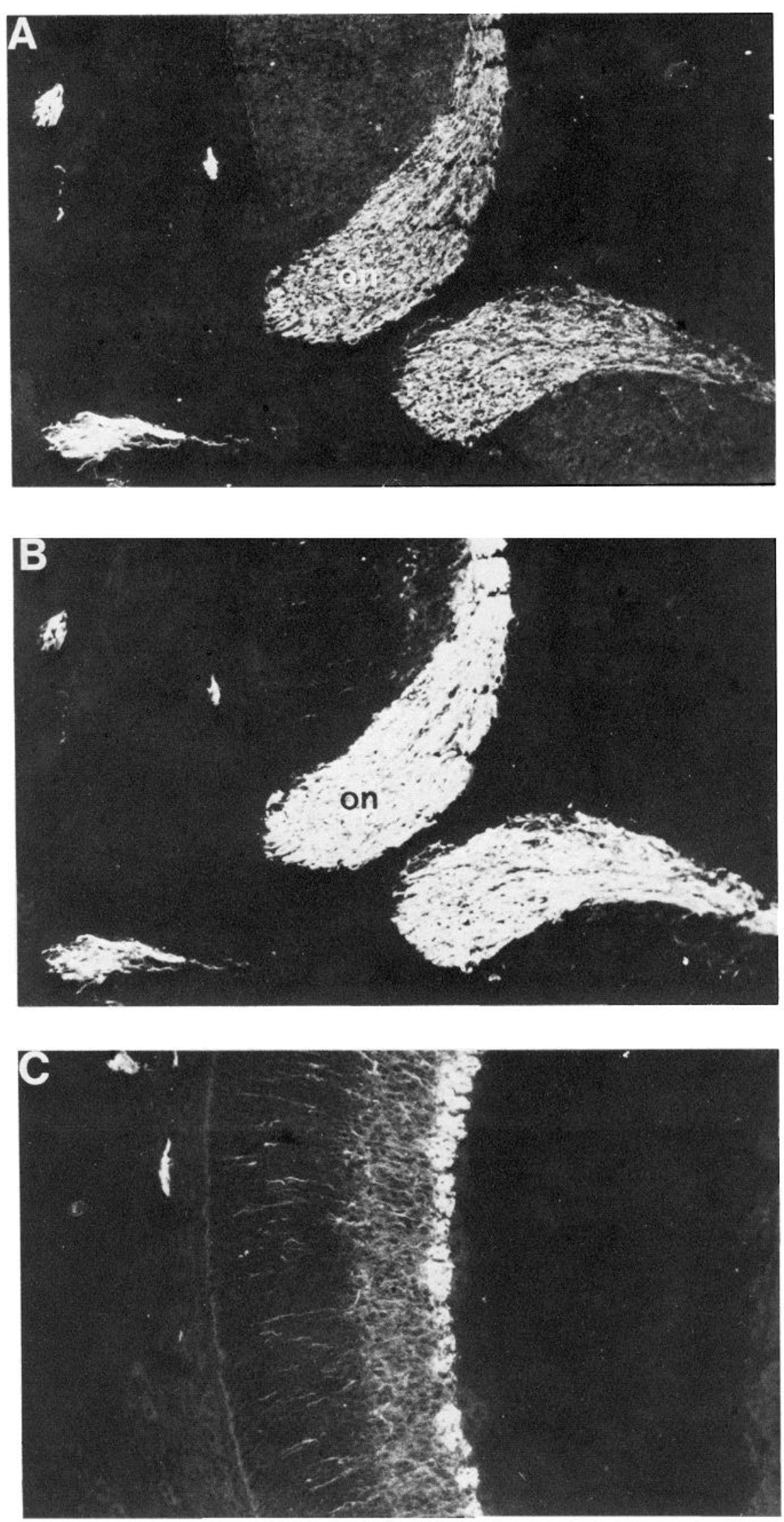

Figure 11. Early expression of $\alpha$-internexin in developing brain: retina. Indirect immunofluorescence was performed on E16 rat brain coronal section at the level of the eye, using antibodies to $\alpha$-internexin $(A, C)$, and NF-L $(B)$. Double labeling of sections was performed as described in the text. Both antibodies stain the ganglion cell fibers of the optic nerve (on), as well as several small cranial nerves. Additional staining for $\alpha$-internexin can be seen in radial and horizontal processes in the deeper layers of the retina. Mag. $=410 \times$ $(A, B) ; 820 \times(C)$. 

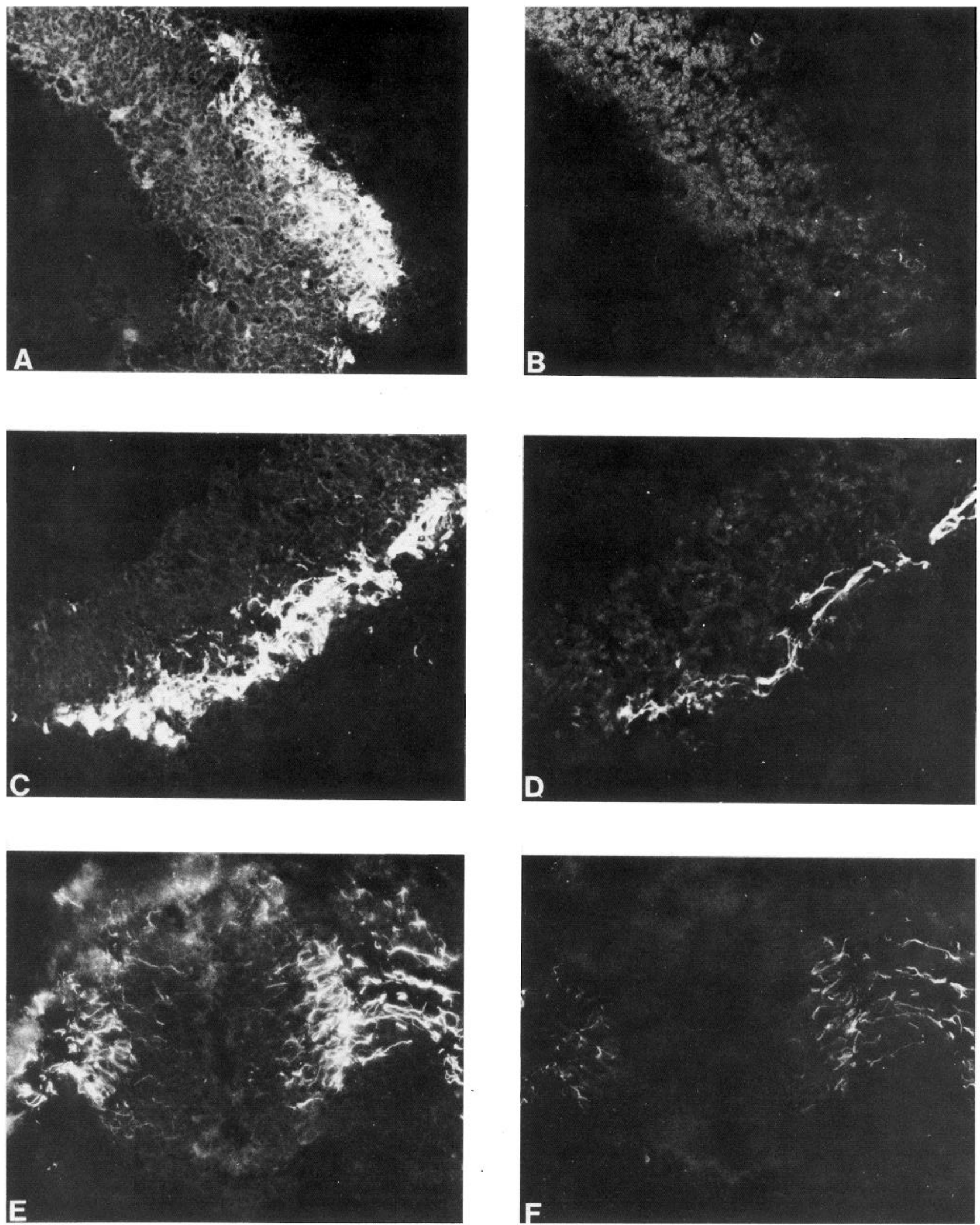

Figure 12. Expression of $\alpha$-internexin and NF-L in developing brain: E12. Indirect immunofluorescence was performed on transverse sections of E12 rat brains; sections were double-labeled with antibodies to $\alpha$-internexin $(A, C$, and $E)$, and NF-L $(B, D$, and $F)$. Strong staining for both proteins was observed in the more caudal regions of the neural tube, from the distal spinal cord $(E, F)$, to the prospective myelencephalon $(C, D)$. Staining for $\alpha$-internexin extended further rostrally, to the level of the prospective midbrain $(A)$, which did not yet stain for NF-L $(B)$. The level of staining in $B$ was comparable to that of controls using the fluorescent second antibodies alone. No staining for either protein was seen in the prospective forebrain (not shown). Mag. $=610 \times$. 
NAPA-73 and $\alpha$-internexin await the publication of the sequence of NAPA-73.

It has long been known that neuronal differentiation is accompanied by changes in neuronal IF composition, usually described as a stepwise process in which expression of NF-H follows coexpression of the 2 smaller subunits (Shaw and Weber, 1982, 1983; Pachter and Liem, 1985; Carden et al., 1987). Additionally, some neurons also express vimentin early in development (Bignami et al., 1982; Cochard and Paulin, 1984), while neurepithelial stem cells express nestin, a novel neuronal IF protein (Lendahl et al., 1990). Our data indicate that the expression of $\alpha$-internexin precedes that of NF-L throughout most of the developing brain and that embryonic neuronal IFs contain an elevated proportion of $\alpha$-internexin relative to their adult counterparts. This can be seen most clearly in the E16 embryos (Figs. 9-11). The same antibodies and dilutions that produced comparable patterns and levels of staining in the adult yielded widely dissimilar results in the embryos, with strong staining for $\alpha$-internexin in processes that still displayed very little NFL. For example, strong staining for both proteins could be seen in the optic nerve, the brain stem and spinal cord, and also the cranial nerves and their ganglia, structures already well developed by E16. Both proteins can be seen in the thalamocortical projections underlying the cortical plate, but staining for $\alpha$-internexin is far stronger and more extensive. In the cerebral cortex, which is still relatively undeveloped at E16, $\alpha$-internexin can be detected in the processes of the horizontal cells of layer $\mathrm{I}$, and also in the radial processes of neurons in layers $\mathrm{V}$ and VI; expression of NF-L in the cortex at E16 is limited to the aforementioned thalamocortical projections, whose development precedes that of the cortical plate (Hicks and D'Amato, 1968; Altman and Bayer, 1979). While further studies are needed to clarify the time course and significance of this early expression of $\alpha$-internexin [in particular, its relationship to early expression of vimentin (Bignami et al., 1982; Cochard and Paulin, 1984), nestin (Lendahl et al., 1990), and peripherin (Troy et al., 1990)], the early onset, high intensity, and long duration of its expression suggest that $\alpha$-internexin may be highly useful as an early neuronal marker.

A consideration of these changes in neuronal IF composition accompanying development may provide some insight into the respective functional contributions of the constituent proteins to neuronal IF function in the adult. The axons of the early, developing nervous system are distinguished most obviously from their adult counterparts by their smaller diameter. In light of the widely accepted theory of neuronal IFs as arbiters of axonal caliber (Lasek et al., 1983), the preponderance of $\alpha$-internexin in the neuronal IF networks of these smaller axons suggests that the ability of neuronal IFs to increase axonal diameter must derive from the properties of one or more of the other neuronal IF proteins. The most obvious candidates for such a role are the 2 larger subunits, NF-M and NF-H, which could affect axonal diameter either by the formation of radially oriented cross-bridges between filaments or by simple, mechanical "space filling" by their large carboxy-terminal projections. Filaments composed predominantly of $\alpha$-internexin would have fewer of these bulky radial projections. Neuronal IFs may thus regulate axonal diameter through changes not only in their number, but also in their composition, with the changes described above allowing for a gradual increase in axonal diameter. This model would also account for the high levels of $\alpha$-internexin we observed in the small-caliber parallel fibers of the adult cerebellum, which appeared to lack other NF triplet proteins (as opposed to the numerous larger fibers in the cerebellum, which expressed all 4 neuronal IF proteins). The absence of lengthy carboxy-terminal extension would seem to make $\alpha$-internexin ideally suited to form IFs in developing axons, but does not explain why this function might not be performed just as well by NF-L, which shares this feature. The answer may relate to the relative abilities of these proteins to mediate interactions between IFs and other organelles, such as (but not only) the microtubules. Interactions between IFs and microtubules would presumably be mediated by microtubule-associated proteins (MAPs), which are believed to bind to NF-L (Heimann et al., 1985); in fact, $\alpha$-internexin has the highest degree of homology not to NF-L, but to NF-M, which reportedly does not bind MAPs. These differences in binding characteristics (which need to be further elucidated) may provide for additional control of axonal diameter and/or regulation of the dynamics and stability of the neurofilament network.

Changes in IF composition have also been observed in the peripheral nervous system following axotomy. Expression of peripherin and vimentin increased immediately following axotomy, while expression of the neurofilament triplet proteins was markedly reduced (Oblinger et al., 1989). Although we found only low levels of $\alpha$-internexin in adult peripheral structures such as sciatic nerve, in agreement with the findings of Chiu et al. for their $66 \mathrm{kDa}$ protein (1989), and also with those of Monaco et al. for their $64 \mathrm{kDa}$ protein (1985), significant levels of $\alpha$-internexin were observed at E1 2 in the developing dorsal roots (Fig. 12) and at E16 in at least one peripheral nervous system (PNS) structure, the trigeminal ganglia (not shown). While a detailed consideration of neuronal IF expression in the PNS is beyond the scope of this paper, these preliminary results suggest an elevated peripheral expression of $\alpha$-internexin in the embryo, which is down-regulated as development proceeds. This view is also supported by the work of Chiu et al. (1989), who report elevated amounts of their $66 \mathrm{kDa}$ protein in sciatic nerve at postnatal day 1 , compared to adult levels. In light of the proposed recapitulation of the developmental program of cytoskeletal expression during axon regeneration (Hoffman and Cleveland, 1988), it will be interesting to see whether PNS expression of $\alpha$-internexin increases following axotomy, or rather, whether $\alpha$-internexin and peripherin may play analogous roles in the CNS and PNS, respectively.

\section{References}

Altman J, Bayer S (1979) Development of the diencephalon of the rat. J Comp Neurol 188:455-524.

Angevine JB Jr, Sidman RL (1961) Autoradiographic study of cell migration during histogenesis of cerebral cortex in the mouse. Nature 192:766-768.

Berry M, Rogers AW (1965) The migration of neuroblasts in the developing cerebral cortex. J Anat 99:691-709.

Bignami A, Raju T, Dahl D (1982) Localization of vimentin, the nonspecific intermediate filament protein, in embryonal glia and in early differentiating neurons. Dev Biol 91:286-295.

Boulder Committee (1970) Embryonic vertebrate central nervous system: revised tcrminology. Anat Rec 166:257-261.

Carden MJ, Trojanowski JQ, Schlaepfer WW, Lee VMY (1987) Twostage expression of neurofilament polypeptides during rat neurogenesis with early establishment of adult phosphorylation patterns. J Neurosci 7:3489-3504.

Chin SSM, Liem RKH (1989) Expression of rat neurofilament proteins NF-L and NF-M in transfected non-neuronal cells. Eur J Cell Biol 50:475-490.

Chin SSM, Hashim GA, Liem RKH (1989) Expression of truncated 
neurofilament proteins in transiently transfected cells. J Cell Biol Abstr 109(4):69a.

Chiu FC, Barnes EA, Das K, Haley J, Socolow P, Macaluso FP, Fant J (1989) Characterization of a novel 66-kD subunit of mammalian neurofilaments. Neuron 2:1435-1445.

Ciment G, Ressler A, Letourneau PC, Weston JA (1986) A novel intermediate filament-associated protein, NAPA-73, that binds to different filament types at different stages of nervous system development. J Cell Biol 102:246-251.

Cochard P, Paulin D (1984) Initial expression of neurofilaments and vimentin in the central and peripheral nervous system of the mouse embryo in vivo. J Neurosci 4:2080-2094.

Dahl D, Rueger DC, Bignami A, Weber K, Osborn M (1981) Vimentin, the $57,000 \mathrm{kD}$ protein of fibroblast filaments, is the major cytoskeletal component in immature glia. Eur J Cell Biol 24:191-196.

Fliegner KH, Ching GY, Liem RKH (1990) The predicted amino acid sequence of $\alpha$-internexin is that of a novel neuronal intermediate filament protein. EMBO J 9:749-755.

Heimann R, Shelanski ML, Liem RKH (1985) Specific binding of microtubule-associated protcins to the 70,000 dalton ncurofilament subunit. J Biol Chem 260:2160-2166.

Hendrickson AE, Cowan WM (1971) Changes in the rate of axoplasmic transport during postnatal development of the rabbit's optic nerve and tract. Exp Neurol 30:403-422.

Hicks SP, D'Amato CJ (1968) Cell migrations to the isocortex in the rat. Anat Rec 160:619-634.

Hirokawa N, Glicksman MA, Willard M (1984) Organization of mammalian neurofilament polypeptides within the neuronal cytoskeleton. J Cell Biol 98:1523-1536.

Hoffman PN, Cleveland DW (1988) Neurofilament and tubulin expression recapitulates the developmental program during axonal regeneration: induction of a $\beta$-specific isotype. Proc Natl Acad Sci USA 5:4530-4533.

Iloffman PN, Lasek RJ (1975) The slow component of axonal transport. Identification of major structural polypeptides of the axon and their generality among mammalian neurons. J Cell Biol 66:351-366.

Kohler G, Milstein C (1976) Derivation of specific antibody-producing tissue culture and tumor lines by cell fusion. Eur J Immunol 6:511519.

Laemmli UK (1970) Cleavage of structural proteins during the assembly of the head of bacteriophage T4. Nature 7:680-685.

Lasek RJ, Oblinger MM, Drake PF (1983) The molecular biology of neuronal geometry: the expression of neurofilament genes influences axonal diameter. Cold Spring Harbor Symp Quant Biol 48:431-444.

Lendahl U, Zimmerman LB, McKay RDG (1990) CNS stem cells express a new class of intermediate filament proteins. Cell 60:585595.

Leonard GB, Gorham DG, Cole P, Greene LA, Ziff EB (1988) A ncrve growth factor-regulated messenger RNA encodes a new intermediate filament protein. J Cell Biol 106:181-193.

Liem RKH, Hutchison SB (1982) Purification of the individual components of the neurofilament triplet: filament assembly from the 70,000 dalton subunit. Biochemistry 21:3221-3226.

Liem RKH, Yen S-H, Salomon GD, Shelanski ML (1978) Intermediate filaments in nervous tissue. J Cell Biol 79:637-645.

McConnell SK, Gnosh A, Shatz CJ (1989) Subplate neurons pioneer the first axon pathway from the cerebral cortex. Science 245:978982.

Monaco S, Antilio-Gambetti L, Zabel D, Gambetti P (1985) Giant axonal neuropathy: acceleration of neurofilament transport in optic axons. Proc Natl Acad Sci USA 82:920-924.

Monteiro M, Cleveland D (1989) Expression of NF-L and NF-M in fibroblasts reveals coassembly of neurofilament and vimentin subunits. J Cell Biol 108:579-593.
Oblinger MM, Wong J, Parysek LM (1989) Axotomy-induced changes in the expression of a type III neuronal intermediate filament gene. J Neurosci 9:3766-3775.

O'Farrell PH (1975) High-resolution two-dimensional electrophoresis of proteins. J Biol Chem 250:4007-4021.

Pachter JS, Liem RKH (1984) The differential appearance of neurofilament triplet polypeptides in the developing rat optic nerve. Dev Biol 103:200-210.

Pachter JS, Liem RKH (1985) $\alpha$-Internexin, a $66-\mathrm{kD}$ intermediate filament-binding protein from mammalian central nervous tissues. J Cell Biol 101:1316-1322.

Parysek LM, Goldman R (1987) Characterization of intermediate filaments in PC12 cells. J Neurosci 7:781-791.

Portier M-M, deNechaud B, Gros F (1984) Peripherin, a new member of the intermediate filament protein family. Dev Neurosci 6:335-344.

Quinlan R, Franke WW (1982) Heteropolymeric filaments of vimentin and desmin in vascular smooth muscle tissue and cultured baby hamster kidney cells demonstrated by chemical cross-linking. Proc Natl Acad Sci USA 79:3452-3456.

Racdler A, Sicvers J (1976) Light and electron microscopical studies on specific cells of the marginal zone in the developing rat cerebral cortex. Anat Embryol 149:173-181.

Ramon y Cajal S (1891) Sur la structure de l'ecorce cerebrale de quelques mammiferes. Cellule 7:125-176.

Retzius G (1893) Die Cajal'schen zellen des Grosshirnrinde beim Menschen und bei Saugetieren. Biol Untersuch 5:1-9.

Reynolds ES (1963) The use of lead citrate at high $\mathrm{pH}$ as an electronopaque stain in electron microscopy. J Cell Biol 17:208-212.

Shaw G (1990) Neurofilament proteins. In: The neuronal cytoskeleton (Burgoyne RD, ed). New York: Liss (in press).

Shaw G, Weber K (1982) Differential expression of neurofilament triplet proteins in brain development. Nature 298:277-279.

Shaw G, Weber K (1983) The structure and development of the rat retina: an immunofluorescence microscopical study using antibodies specific for intermediate filament proteins. Eur J Cell Biol 30:219232.

Shaw G, Banker GA, Weber K (1985) An immunofluorescence study of neurofilament protein expression by developing hippocampal neurons in tissue culture. Eur J Cell Biol 39:205-216.

Shaw G, Osborn M, Weber K (1986) Reactivity of a panel of neurofilament antibodies on phosphorylated and dephosphorylated neurofilaments. Eur J Cell Biol 42:1-9.

Steinert PM, Roop DR (1988) Molecular and cellular biology of intermediate filaments. Annu Rev Biochem 57:593-625.

Towbin H, Staehlin T, Gordon J (1979) Electrophoretic transfer of proteins nitrocellulose: procedure and some applications. Proc Natl Acad Sci USA 76:4350-4354.

Troy C, Brown K, Grcenc LA, Shclanski ML (1990) The ontogeny of peripherin, a type III neuronal intermediate filament protein. Neuroscience (in press).

Wang E, Cairncross JG, Liem RKH (1984) Identification of glial filament protein and vimentin in the same intermediate filament system in human glioma cells. Proc Natl Acad Sci USA 81:2102-2106.

Willard M, Simon C (1981) Antibody decoration of neurofilaments. J Cell Biol 89:198-205.

Willard M, Simon C (1983) Modulations of neurofilament axonal transport during the development of rabbit retinal ganglion cells. Cell 35:551-559.

Wu DK, de Vellis J (1987) The expression of the intermediate filament-associated protein (NAPA-73) is associated with the stage of terminal differentiation of chick brain neurons. Brain Res 421:186193. 